\title{
DESIGN OF PROMOTION MEDIA FOR REOG PONOROGO WITH GRAPHIC MOTION OF WAYANG KULIT
}

\author{
Gheraldi Waskito Ajiprabowo ${ }^{1}$ and Handriyotopo ${ }^{2}$ \\ ${ }^{1}$ Indonesian Insitute of the Arts Surakarta, Indonesia \\ ${ }^{2}$ Indonesian Insitute of the Arts Surakarta, Indonesia \\ E-mail correspondence: Gheraldi95@gmail.com
}

\begin{abstract}
Reog Ponorogo art is an Indonesian cultural heritage that must be preserved in the mid of current cultural competition nowadays. One of the ways to preserve Reog art is by introducing it to the wider community, especially the younger generation. The purpose of this design is to produce motion graphic media to introduce Reog Ponorogo traditional art. This design uses the $5 \mathrm{~W}+1 \mathrm{H}$ approach, with the following stages: 1) reviewing the problems; 2) developing with the relevant questions; 3) developing the answers of those questions; 4) making the right solution. The result of this study shows that the design of Reog Ponorogo motion graphics can be the right media to provide information about Reog art to the public, especially millennial youth. This motion graphic media is quite comprehensive, because it is completed with supporting media such as posters, print ads, merchandise, and Instagram.
\end{abstract}

Keywords: promotion media, motion graphics, and Reog Ponorogo

\begin{abstract}
ABSTRAK
Kesenian Reog Ponorogo merupakan warisan budaya bangsa Indonesia yang harus dilestarikan di tengah persaingan budaya saat ini. Pelestarian kesenian reog dilakukan salah satunya dengan memperkenalkan kepada masyarakat luas terutama generasi muda. Tujuan perancangan ini yaitu menghasilkan media motion graphic untuk memperkenalkan kesenian tradisional Reog Ponorogo. Perancangan ini menggunakan pendekatan $5 W+1 H$, dengan tahapan sebagai berikut: 1) mengkaji ulang masalah; 2) mengembangkan pertanyaan yang relevan; 3) mengembangkan jawaban atas pertanyaan tersebut; 4) membuat solusi yang tepat. Hasil penelitian ini menunjukkan bahwa perancangan motion graphic Reog Ponorogo ini dapat menjadi media yang tepat untuk memberikan informasi tentang kesenian Reog kepada masyarakat, terutama pemuda milenial. Media motion graphic ini cukup komprehensif, karena dilengkapi media pendukung seperti poster, print ads, merchandise, dan instagram.
\end{abstract}

Kata kunci: media promosi, motion graphic, dan Reog Ponorogo

\section{Introduction}

Indonesia has a unique and diverse culture. One to another culture has its own characteristics that are distinguished through elements that have lived where they 


\section{Artistic}

come from. Each region has a culture in which there is a unique art that indicates that this is a particular regional art. Indonesian cultural diversity from Sabang to Merauke is a very valuable asset, so they must be maintained and preserved.

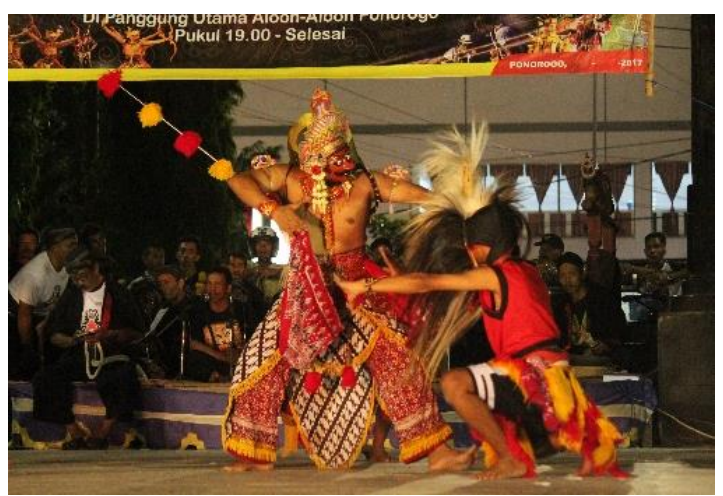

Figure 1. Ponogogo Reog dance

(Photo : Gheraldi Waskito Ajiprabowo. 2018)

One of the worrying phenomena is that Indonesian traditional arts are in great demand by foreign countries, resulting problem in the claiming of ownership of these arts. Apart from the controversy that occurred in 2007, in which Malaysia claimed that Reog Ponorogo was a part of its art, it is a necessary to have more in-depth knowledge about Reog Ponogoro so that people, especially young people, were more familiar with it and knew about this art.

Meanwhile, the progress of science and technology is very rapid, a huge influence on local culture. The creation of motion graphics is done based on this phenomenon. This design uses the parallax scrolling effect by selecting colors, font and layout which are attractive. The final result of this design is expected to be able to give understanding to the community and young generation about the existence of Reog Ponorogo art, so that cultural preservation can be maintained. In addition, this design is expected to be an alternative media in presenting a more modern and creative local culture.

\section{Literature Review}

\subsection{Reyog Ponorogo}

Ponorogo Regency is located in East Java Province, bordering with Central 
Java Province on the west side. Ponorogo Regency is known by the nickname Kota Reog or Bumi Reog, because this area is the place where the Reog art originated. Every direction to the entrance to the Ponorogo Regency is decorated with statues and the gate figures of Reog dancers. Many intersections from the center to the edge of the city exhibit Singo Barong statues or Reog dioramas .

Ponorogo is a city that has an obsession with Reog. Every year in the month of Suro $^{1}$ (Muharram), Ponorogo Regency holds a series of events in the form of people's party, the Grebeg Suro. This art has officially become the possession of this regency. The Ponorogo Regency Government has registered Reog as the copyright property of Ponorogo Regency under the number 026377 on February 11, 2004. This copyright was signed directly by Yusril Ihza Mahendra as the Minister of Law and Human Rights at the time (Nurhani \& Nurlelawati, 2008).

The word Reyog is just a development / change of speech from the word 'Reog', so that the words 'Reyog' and 'Reog' have the same meaning (Hartono, 1980). The word 'Reyog' is also not different from the word 'Riyeg' or 'Reyod' which means broken (Hartono, 1980).

The Reog or Barong art demonstrates the power to lift a "Dadak Merak" (Peacock) weighing about 60 kilograms with the power of tooth bites during the performance. The accompanying instruments are kempul, ketuk, kenong, genggam, ketipung, angklung, and especially "salompret" which sounds "slendro" and "pelog" tone. This tone rises to a mystical atmosphere, strange, exotic and at the same time arouses passion. Basically there are five versions of popular stories that developed in the community about the origin of the Reog and Warok arts.

\subsection{Motion Graphic}

Motion graphics or typographical animation has been used by the film and television industry for decades in order to present and promote movies and TV shows (Schlittler, 2015). Currently the use of motion graphics is increasingly widespread, especially with the large number of motion graphics software that offers convenience

\footnotetext{
${ }^{1}$ month in Javanese calendar
} 


\section{Artistic}

and advantages. In addition, online tutorials both text and video on Youtube are increasingly easy to be gained.

The creation theory in designing motion graphics is the parallax scrolling effect, a technique that refers to changes in the position of framing objects when viewed through two different points of view. This point of view is measured by taking pictures from the angle of inclination between the lines of vision, because an object or a thing that is closer has a greater parallax compared to one object that looks far away when viewed from two different or unequal positions (Lanier, 2010). However, the parallax scrolling effect used in this Reog Ponorogo's motion graphics is a technique on computer graphics, where background images move according to the camera's movement that are slower than foreground images, thus creating an illusion of depth in $2 \mathrm{D}$ scenes.

The technique to bring up the parallax scrolling effect in this motion graphic has to be done with the movement of the animated camera frame. So, parallax effects will automatically appear due to changes in the position of a still object with a background.

\section{Creation Methodology}

This design belongs to the category of Practice-Led Research, also known as Research Through Design. The definition of Practice-Led Research according to Haseman is a research strategy carried out through practice, mainly using certain methodologies and methods that are familiar to practitioners (Guntur \& Sugihartono, 2015). This design is a study with the Reog Ponorogo object, and intended to produce a motion graphic design as a promotional media for Reog Ponorogo.

The design of this Reog Ponorogo's motion graphics uses a 5W $+1 \mathrm{H}$ approach (What, Who, When, Why, Where and How), a method discovered by J.R. Kipling, so

it is called Kipling Method. This is needed to analyze the problems in the design of Reog Ponorogo motion graphics. Steps taken in this method include: 1) reviewing the problems; 2) developing relevant questions using elements of $5 \mathrm{~W}+1 \mathrm{H}$; 3) developing answers to these questions; 4) making the right solution for the problems. 


\section{Discussion}

\subsection{Design Concept}

This motion graphic design is complemented by other supporting media such as posters, print ads, and social media (Instagram and Facebook) also merchandise. The media was designed by containing the origin or story of the formation of Reog Ponorogo. Later the media will be uploaded and published via Youtube. Because of its characteristic as a supporting media, so the use of color illustrations, text, or fonts are the same as in motion graphics.

\subsection{Target Audience}

The target audience for this motion graphic design is teenagers and adults of 10-35 years old. Demographically, the target audience in delivering this motion graphic is divided into two namely primary and secondary targets. Primary targets are aimed at Indonesian youth, with the following details.
a. Gender: Male and female
b. Age: 10-22 years old
c. Religion: All religions
d. Education: Students and university students

Meanwhile, secondary targets (indirect targets) are aimed at the people of Indonesia as a whole. The role of parents and the community functions as a mediator in giving information to children.

Psychographic aspects of this design can be explained that the segmentation is based on lifestyle and human personality. Lifestyle affects one's behavior and ultimately determines one's consumption choices. Lifestyle is a mirror of someone in spending their time and money expressed in their activities, interests and opinions. The target audience in this design which is seen from psychographic aspects, namely:
a. Have a personal gadget.
b. Have a social media account.
c. Liked the latest information updates. 


\section{Artistic}

d. Often open the internet or Youtube to watch or upload videos.

As for the Geographic aspects in this design, it can be explained that Reog Ponorogo's motion graphic media is aimed at all teenagers and the community in Indonesia.

\subsection{Media Concepts}

The concept used or applied in the chosen media is to use two approaches namely a visual approach and a verbal approach. First, a visual approach is an approach that is carried out through visual elements in a design work, including:

1). Typography

Typography is very important in the design of this work, both as a complement and as a main element. Typography used is the type of Sans-serif and Serif. This typeletter is used as a headline because of the low readability level, while the Serif typeface is used for explanatory text because of the high level of legibility. Serif functions as a connecting that virtually can bridge the space between one letter to another. Therefore, Serif letters can cause eye work to be lighter when reading large amounts of text (Sihombing, 2001). The typeface used in this design are: Trajan Pro and Iskoola Pota.

2). Illustration

Illustration is an explanatory element in a graphic design work. The illustrations used are the characters that have been previously designed and made in motion graphic works. Because the design work created is promoting the main media, so the elements used are the same and in accordance with the concept of motion graphics. The illustrations are "gunungan" and puppet figures of a combination of Reog Ponorogo. This illustration uses a vector design style that incorporates wayang kulit (puppet) visualization that has been simplified, combined and adapted to the original characters in the Reog Ponorogo performance.

3). Colors

Color is an element that is also important in the design of a design work. Color in the publication media can affect the target audience. The colors used in this design are the colors that are commonly found in Reog Ponorogo performances. In addition, 
it is added to the traditional colors contained in the shadow puppet show. The colors used in motion graphics and promotional media Reog Ponorogo are:

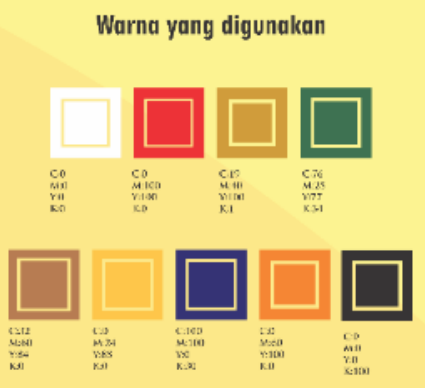

Figure 2. Color concept used

\section{4). Layout}

Layout is the arrangement of elements that are combined in a single unit. Layout is designed as simple as possible so that communication messages from the media designed can be conveyed to the audience or public. And also the aesthetics of a design work should be interesting so that the level of interest to see the design work is high. The following is a layout sketch that will be applied later in the design of print media both posters, print ads and social media works.

Second, the verbal approach is an approach that is done through verbal elements in a design work, including:

a). Headline

Headline is the text or sentence that is at the foremost appearance in a design work and has a big role in attracting the attention of the audience. Headlines have a larger font size than other text. Minimum headline size is $14 \mathrm{pt}$. The design of poster media and print ads, the text used is "REOG PONOROGO".

b). Bodycopy

Bodycopy is the explanatory text of the main elements as a product or graphic design appearance that has been designed. Usually bodycopy uses sentences that are persuasive and communicative. Bodycopy is designed using simple words to be easily 


\section{Artistic}

understood by the target audience. The bodycopy used in this design is a brief description of the posters or print ads created.

c). Baseline

Baseline is a sentence under the bodycopy. Usually functioned as a signature or organizer or the name of the company conducting a promotion. This section is published as a form of responsibility for the content of advertisements (Kusrianto, 2007). Baseline in this design is the Visual Communication Design Study Program in collaboration with the Tourism Office of Ponorogo Regency, East Java.

\subsection{Design Process}

The design process is carried out with several stages both in the making of the main media and supporting media. This section will explain the process of making these two media. There are several stages in the design of the main media namely motion graphics, which can be illustrated in the scheme below.

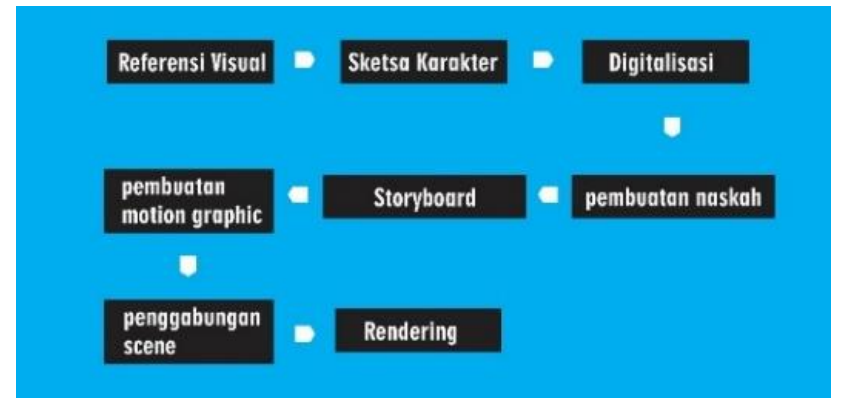

Figure 3. Schematic of the motion graphic design process

The design of supporting media has several stages that are almost the same as the main media. The chart below shows the different stages.

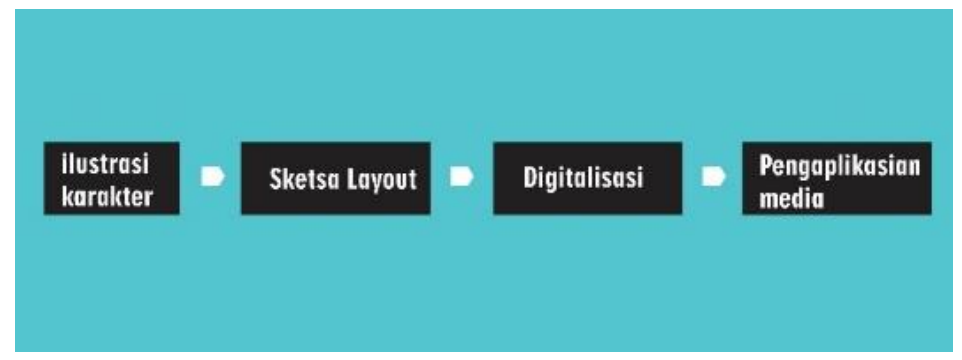

Figure 4. Schematic of the process of making supporting media 
The process of making the main media in the form of motion graphics is done with software Adobe After Effect CC 2017. The making process starts with the rigging process using the DUIK Plug-in. This is done after the characters are imported into the software.

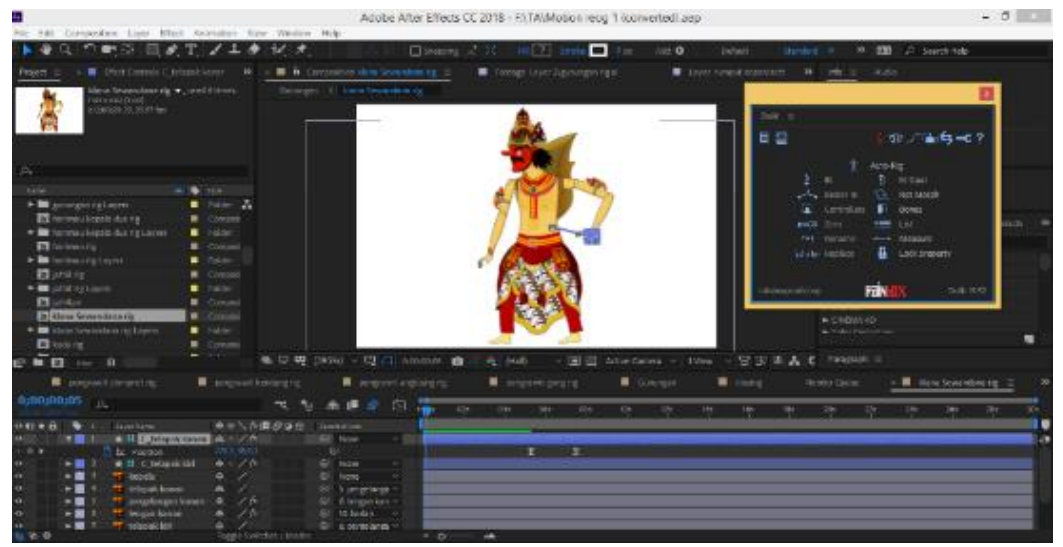

Figure 5. The character rigging process

After rigging all the characters are finished, all the other design elements are imported and moved according to the storyboard. The following is the process of moving characters and other design elements in each scene.

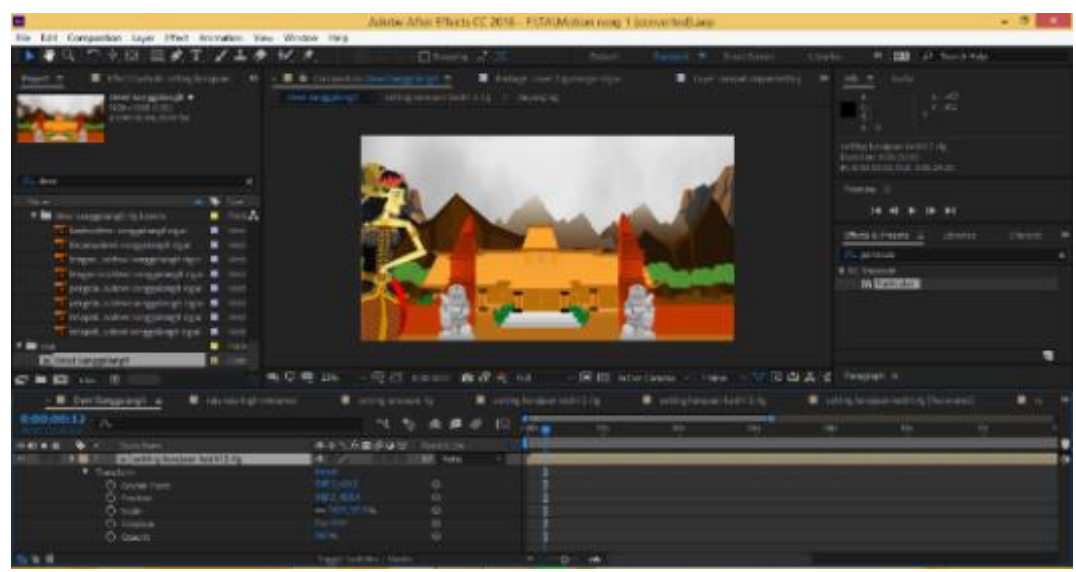

Figure 6. The process of moving characters in each scene

The next process is the rendering process of each scene using Adobe After Effects CC 2017. The video output in this process is set in MP4 format. The following is the rendering process using Adobe Encorder CC 2017. 


\section{Artistic}

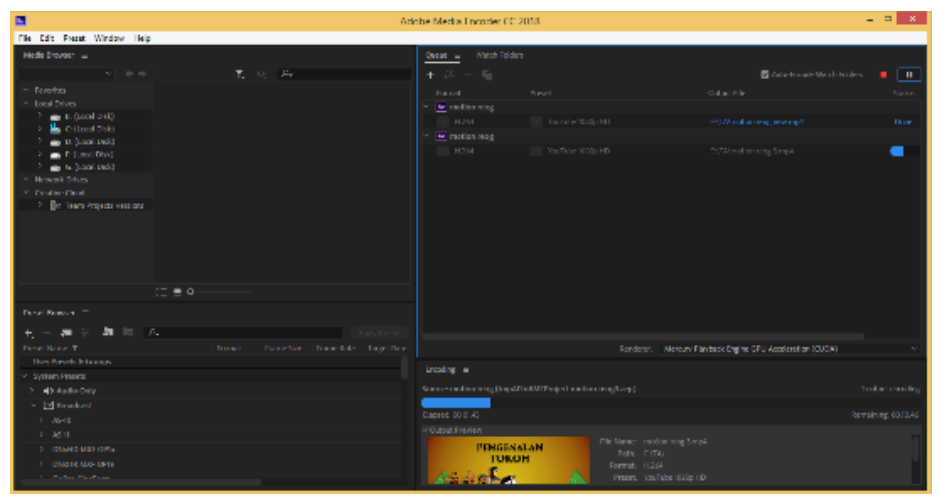

Figure 7. The Rendering process in each scene

After the rendering process is completed, the next step is to merge scenes and editing and also add voice over, transition effects and sound effects using Adobe Premiere Pro CC 2017. Next, the color grading process is done using the lumetry color effect.

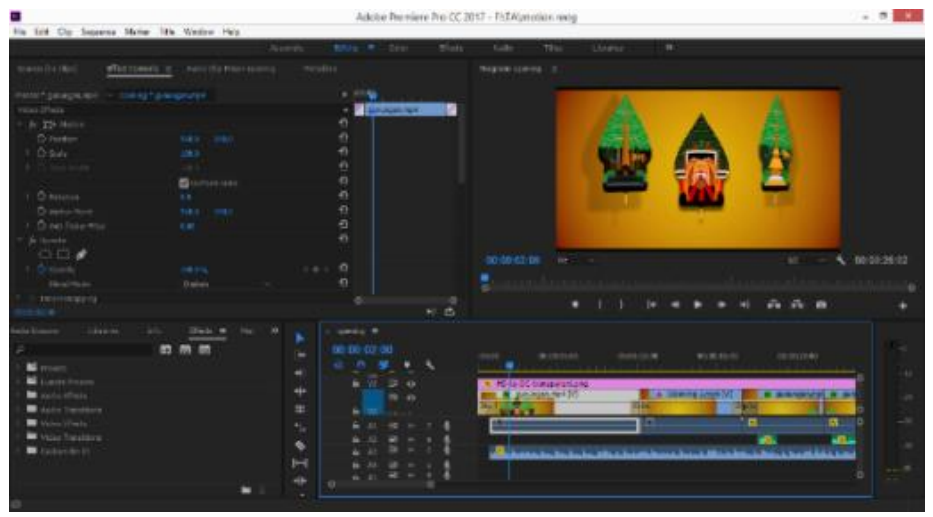

Figure 8. The editing process in Adobe Premiere Pro CC 2017

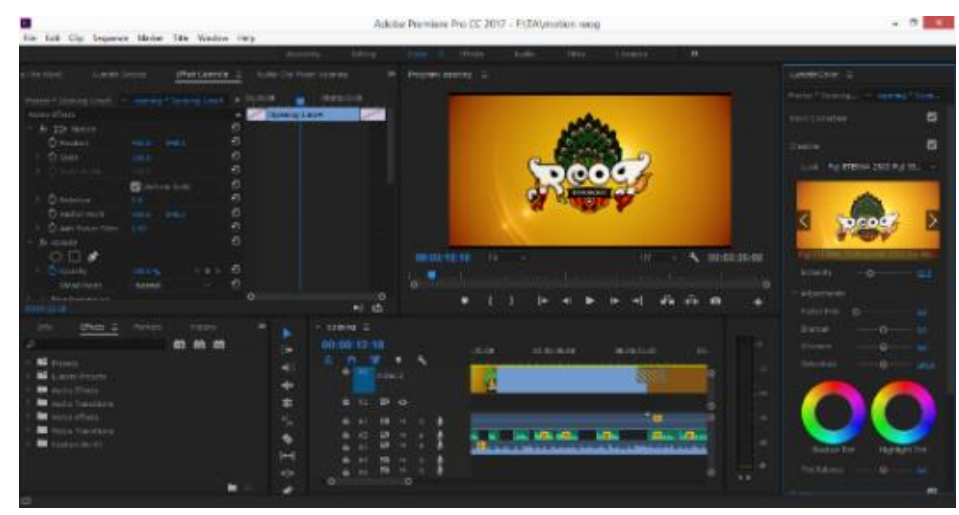

Figure 9. The color grading process in Adobe Premiere Pro CC 2017 
The next stage is the process of exporting videos that have been edited to .mp4 format with a size of $1920 \times 1080 \mathrm{p} 25 \mathrm{fps}$.

The design of the main media is Reog Ponorogo motion graphic using the concept of visualization and motion styles from shadow puppets. The final result of this motion graphic is three minutes in duration with a size of $1920 \times 1080 \mathrm{p} 25 \mathrm{fps}$.
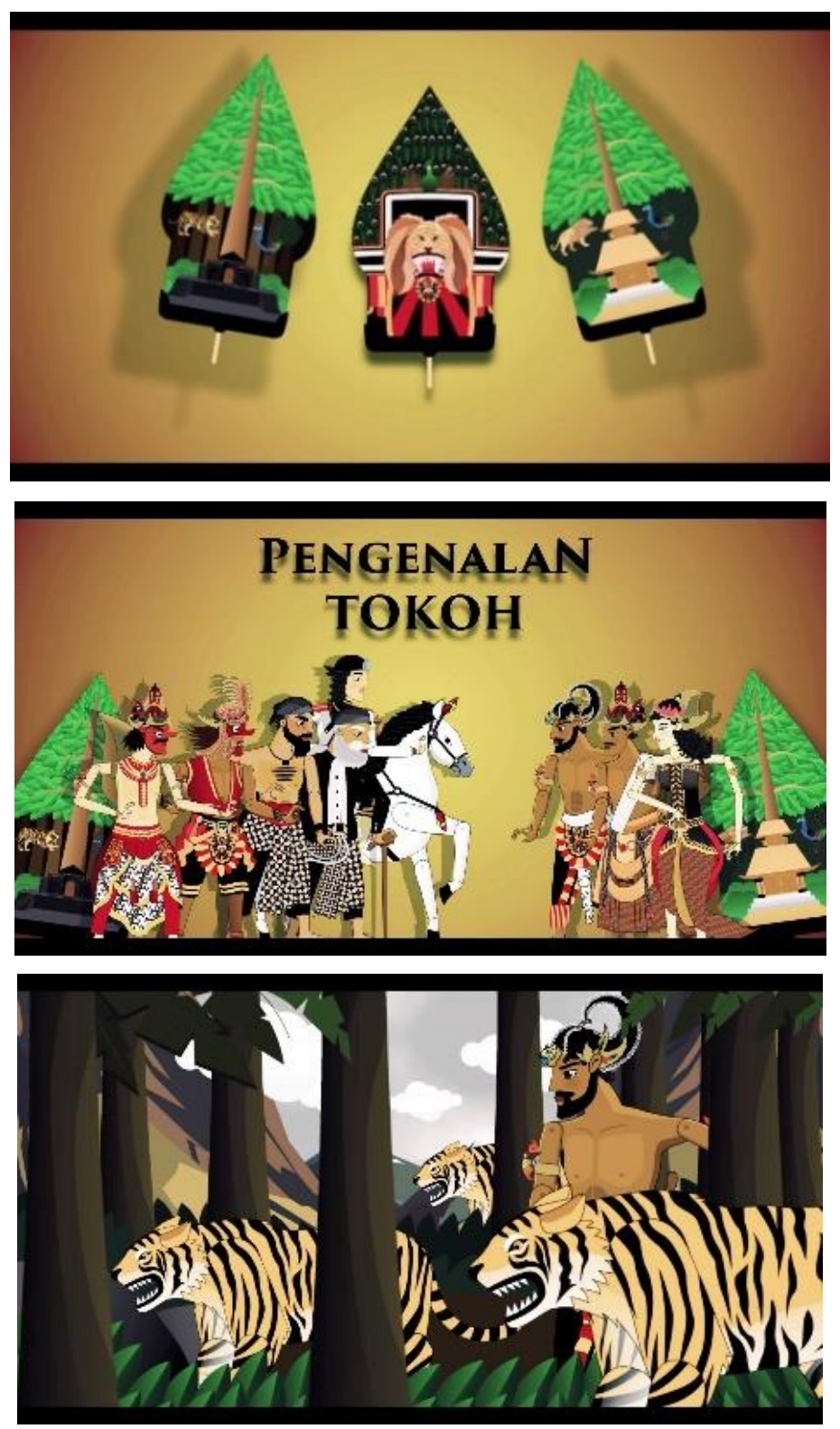

Figure 10. Some motion graphic visualizations 


\section{Artistic}

In addition to the main media in the form of motion graphics, in this design several promotional media have also been produced. This media is used to promote Reog Ponorogo motion graphics and will be uploaded via Youtube, in order to reach many audiences. Below are some promotional media that have been produced, but the creative process is not explained, because they are only supporting media.

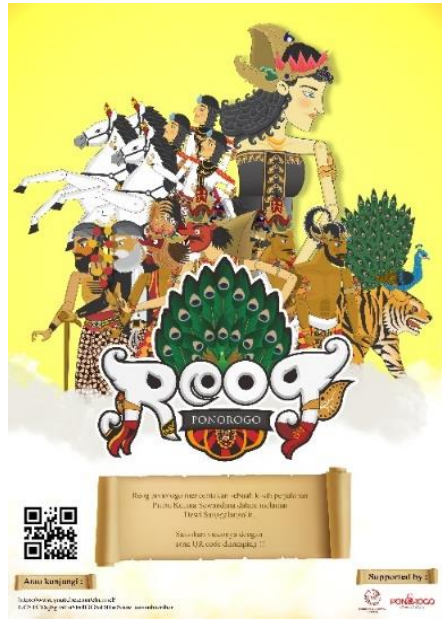

Figure 11. Poster

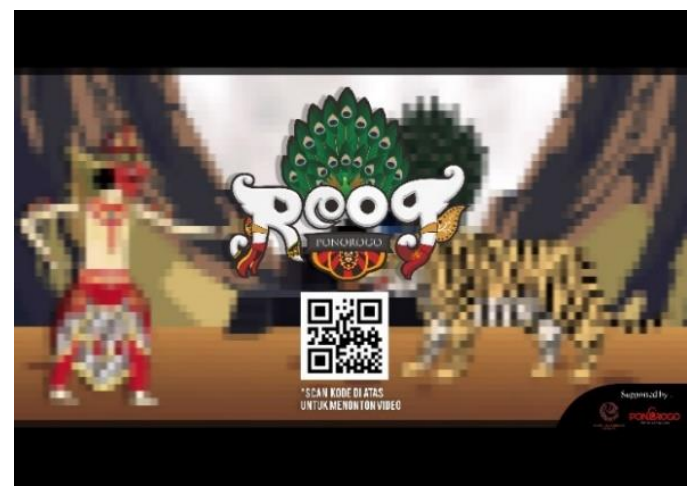

Figure 13. Print ads

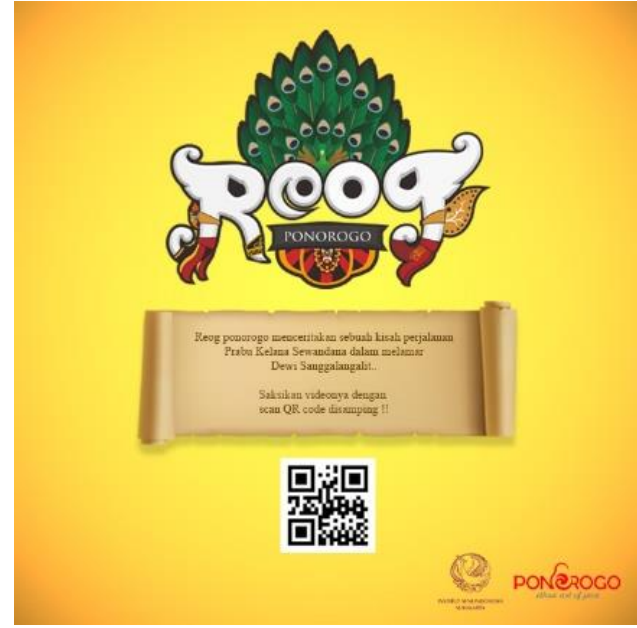

Figure 12. Instagram publication design

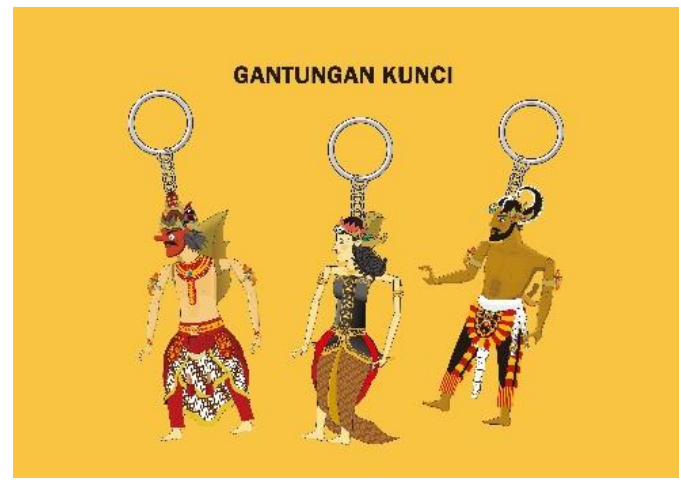

Figure 14. Key chain design

\section{Conclusion}

The conclusion that can be drawn from the design of the Reog Ponorogo motion graphic is that this design of the motion graphic can be a medium to introduce and provide information about Reog art to the public, especially millennial youth. This motion graphic media is quite comprehensive, because it is completed with supporting 
media such as posters, print ads, merchandise, and Instagram. The use of wayang kulit visualization style and parallax effect are the differentiators of this work from previous motion graphic works.

\section{References}

Guntur, \& Sugihartono, R. A. (2015). Metodologi Penelitian Artistik. ISI Press \& P3AI ISI Surakarta.

Hartono. (1980). Reyog Ponorogo. Departemen Pendidikan dan Kebudayaan.

Kusrianto, A. (2007). Pengantar Desain Komunikasi Visual. Andi Offset.

Lanier, L. (2010). Profesional Digital Compositing: Essential Tools and Techniques. Wiley Publishing.

Mapson, L. C. (2010). Kesenian, Identitas dan Hak Cipta: Kasus 'Pencurian' Reog Ponorogo. Universitas Muhammadiyah Malang.

Nurhani, H., \& Nurlelawati, T. (2008). Kesenian Reog Ponorogo. Penerbit PT.Widya Duta Grafika.

Schlittler, J. P. A. (2015). Motion Graphics and Animation. https://www.researchgate.net/publication/284437924_Motion_Graphics_and _Animation

Sihombing, D. (2001). Tipografi. Gramedia Utama. 